\title{
STUDY OF SITUATIONAL ANXIETY IN SNOW SPORT COURSES
}

\section{Milena Zdravcheva, Krastyo Zgurovski}

Summary: The efficiency of snow sports courses is determined by different methods of obtaining feedback on the perceptions of the students, establishing gender-based levels of anxiety and tracking their dynamics in the course of education. There is a clear tendency to reduce stagnation anxiety between the stages of this study. Data analysis will help us to create conditions for easier psychological adaptation of students.

Key words: training and stress, Ch. Spielberger's test, learning efficiency, anxiety dynamics

\section{Introduction}

Snow Sports Courses have a long tradition in the NSA. They represent an educational format with a wide-ranging educational impact aimed at building habits for safe high mountain behavior and ecological attitude towards nature, at mastery of skills in snow sports and key competencies necessary for organizing and conducting a large group training process people under specific conditions.

According to past studies on the problem at issue (Khavezova, Yancheva, 1996), the most significant factors causing anxiety among novice skiers, such as most snowboard students, are the slope of the terrain, the speed, the movement of other skiers along the track, the atmosphere in the mountains, the specific equipment, the presence of past injuries, the behavior and skills of the ski teacher (Khavezova, Yancheva, 1996), the domestic and social environment. We think that these studies have been relevant to their time, but education in snow sports is a dynamic educational form that requires such studies to be conducted periodically, depending on the changing material and technical base and the different physical, mental and social profile of the students.

The effectiveness of the learning process is linked to different methods of individual control and feedback on learner perceptions. In situations involving high mental tensions, personal and situational anxiety and the level of self-control skills are just some of the many factors that determine the behavior of the individual (Domuschieva-Rogleva, Petkova, 2002). In our view, these factors are key to the effectiveness of the learning process. Looking at the concept of Ch. Spielberger, which brings out two main types of anxiety - personal and situational (Spilberger, 1983),- we have focused on choosing several features that we consider appropriate in this work.

Since situational anxiety refers to dynamic mental states, it occurs when a particular stimulus or situation is perceived as having actual or potential elements of danger, threat, and harm. In the context of the concept of genesis of stress situational anxiety is a function of the ratio of need - opportunities to satisfying the need. The low of satisfying the need combined with a high need, determined by internal or external factors, leads to an increase in situational anxiety (Spilberger, 1983).

The testing character of the ski course as a format largely determines similar processes. However, our assumption is that it has a positive impact on the level of anxiety in NSA students.

\section{Purpose:}

Research of the situation-related anxiety at the NSA students at the beginning and the end of the course in snow sports in the period 29.01.2017-24.02.2017

\section{Tasks:}

1. Establishing and analyzing the mean values by gender for 1 st and 2 nd studies.

2. Determining the mean value and percentage ratio of S-anxiety total for all subjects tested for each test individually

3. Analysis of the percentage distribution of S-anxiety at the beginning and end of the study for all subjects.

The data we receive will be useful for the effectiveness of snow sports courses, by enhancing the control of the learning process and improving student feedback. Ensuring an optimal psychological environment for conducting the form is essential to its performance and there are currently no current surveys related to the "Snow Sports" course. We consider that identifying levels of gender anxiety and tracking their dynamics in the course of learning will help us to create conditions for easier psychological adaptation of students. It is also a bold 
basis for future studies of anxiety.

\section{Methodology and methods}

To solve specific tasks and to achieve the purpose of the study, we used a comprehensive methodology that includes:

1. Investigating sources of information.

2. Psychological test to measure situational anxiety.

Ch. Spielberger's test was developed on the basis of his theoretical concept of anxiety. Differentiating the anxiety of the personality and the situational condition determines the creation of two forms for their evaluation STAY-Y-1 (for assessment of situational anxiety - S) and STAY-Y-I (for evaluation of personal anxiety $-\mathrm{T})$. Each of the forms contains 20 statements and a 4-degree scale of the liqueur type to assess the intensity of anxiety. The range of scores ranges from 20 to 80 , with the rise of the ball in the direction of increasing anxiety. S-scale testing is carried out first, followed by the T-scale, but only one form may be used according to the task of the study (Shtetinski, Paspalanov, 1989). For the purpose of our study, we conducted STAI-Form Y-1 tests at the beginning and end of each study period.

3. Testing 142 students ( 36 women and 106 men) participating in the "Snow Sports" course.

4. Processing of test data for the period under review.

5. Comparative analysis.

The survey was conducted in the period 29.01.201724.02.2017 during the "Snow Sports" course.

\section{Results and discussion}

the results for all subjects were obtained using the methodological tool for working with the Bulgarian version of C. Spielberger's questionnaire for anxiety assessment.

In Table 1 lists the norms under which the results are calculated.

Table 1. Stable anxiety standards

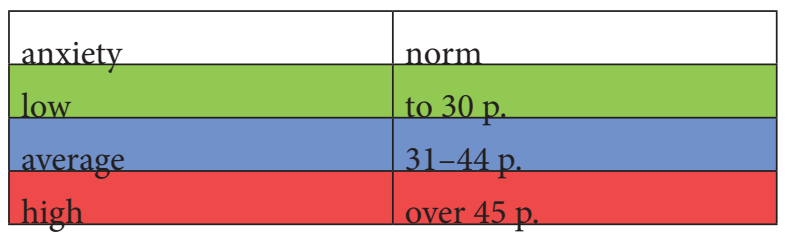

We categorized the data obtained for all 142 persons surveyed by gender and by shift. Table 2 presents the median results for both genders at the beginning and end of the study.

To better illustrate the differences, we converted the averaged results as a percentage to the maximum number of points in the test (Figure 1).

Table 2. Average test results, established by gender sign

\begin{tabular}{|l|l|l|}
\hline & First study & Second study \\
\hline Average score for women & $38,88 \mathrm{p}$. & $33,53 \mathrm{p}$. \\
\hline Average score for men & $34,36 \mathrm{p}$. & $34,85 \mathrm{p}$. \\
\hline Average for research & $36,62 \mathrm{p}$. & $34,22 \mathrm{p}$. \\
\hline
\end{tabular}

In a comparative study of the mean results reported by STAY-S in the first study, it was found that women at the start of the study had a mean anxiety level of 38.88 (48.60\%), which was $5.65 \%$ higher than that of men -34.46 points $(42.95 \%)$. The male anxiety range also falls within the average norm (Figure 1). Most publications in the scientific literature show that women are at risk of developing high levels of anxiety (Nijkamp et al. 2004) which is explained by fluctuations in estrogen and progesterone levels - hormones involved in changes affecting anxiety and mood (Weinstock 1999), so the result obtained is in the direction of our expectations.

Situational anxiety is a condition that is greatly influenced by external factors and by the specific racing situations the athlete encounters (Domuschieva-Rogleva, Petkova, 2002).

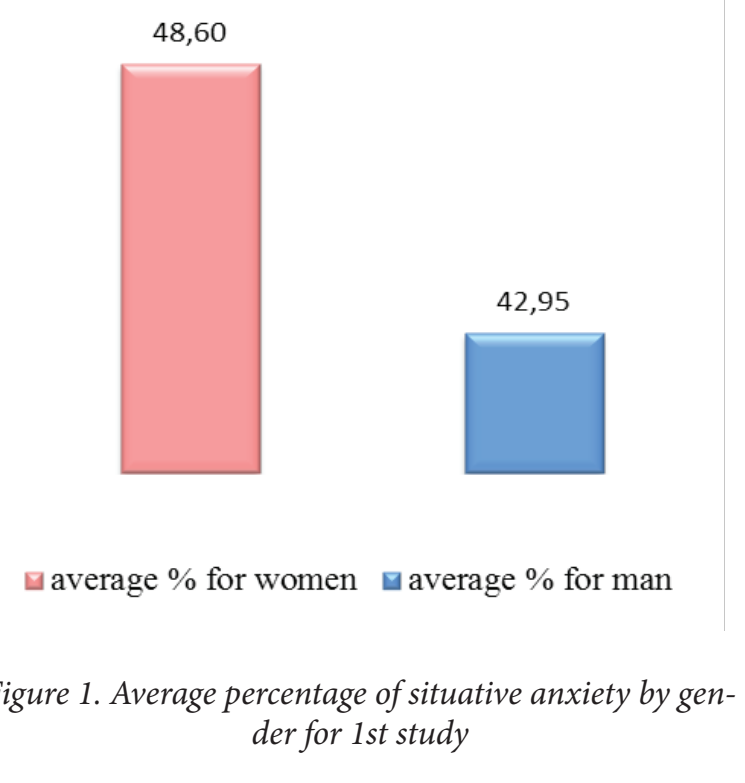




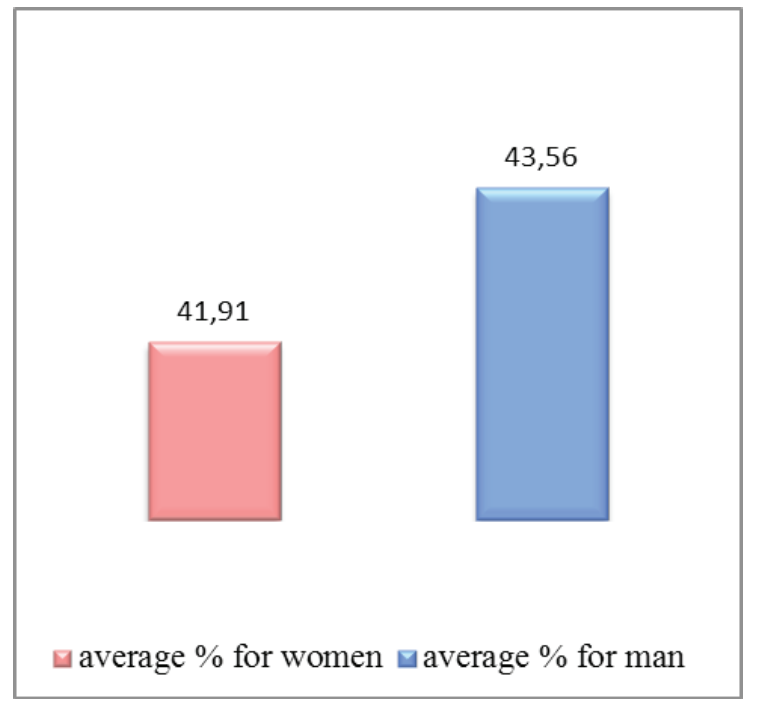

Figure 2. Average rate of site sexual anxiety for $2 n d$ study

However, the analysis of the average results at the end of the study showed significant differences in women's S-anxiety data - 33.52 (41.91\%) or an anxiety decrease of $6.69 \%$, which could be interpreted as projection of subjective experience related to the emotional side of the course.

In men, the results showed minor changes of 34.85 points $(43.56 \%)$ and even showed an increase in anxiety by $0.61 \%$. (Figure 2 ). This could also be due to emotional factors related to non-compliance with the established order, which would result in deserved sanctions and corrective remarks that leave a negative feeling.

Both experimental groups in the first study demonstrated an average level of situational anxiety with almost the same results -36.31 and 36.93 . The differences are almost negligible, from which we can conclude that the new stress environment affects the same gender.

The reported data in total for all subjects showed a decrease in the anxiety at the outcome of the conducted study by $2.4 \%-34.22 \%$, which is below the lower limit of the mean anxiety level (Figure 3) despite the daily stress, caused by factors such as speed, pitch, risky situations, use of ski lifts, intensity and density of exercises and fatigue.

For greater visibility, we will analyze the research anxiety separately (Table 3 ):

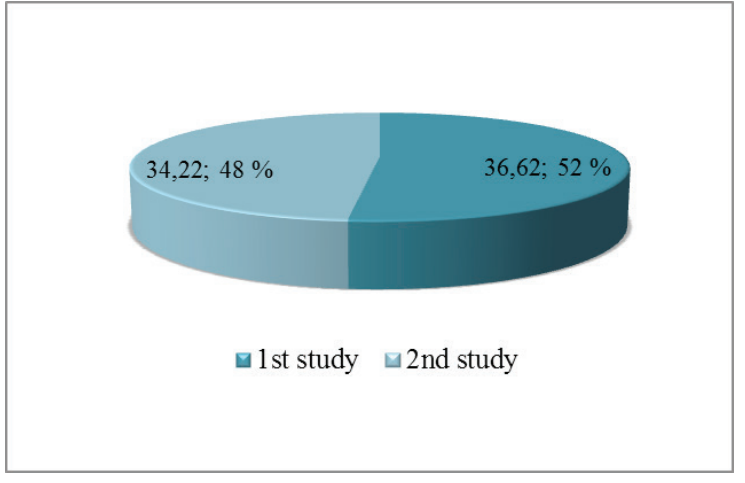

Figure 3. Mean value and percent S-anxiety ratio total for all subjects tested in the individual tests.

Table 3. Percentage of S-scale scores for anxiety by periods.

\begin{tabular}{|l|l|l|}
\hline Anxiety level & 1 st study & 2nd study \\
\hline low & $33,10 \%$ & $35,92 \%$ \\
\hline on average & $53,52 \%$ & $50,70 \%$ \\
\hline high & $13,38 \%$ & $13,38 \%$ \\
\hline
\end{tabular}

Figure 4 shows the differences in percentages for all subjects who demonstrated a certain degree of anxiety in the 1st study.

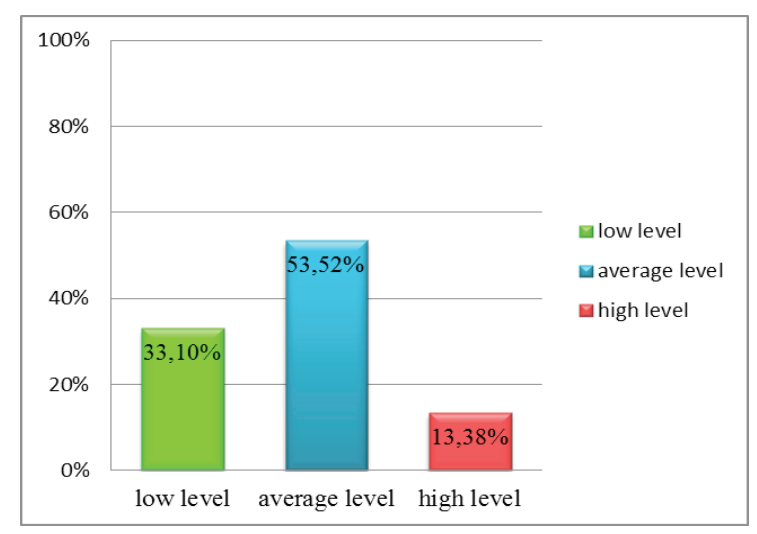

Figure 4. Percentage distribution of the degree of S-anxiety in 1st study.

The graph shows that students respond predominantly to the mean range of situational anxiety: as a percentage ratio in the mean range of $53.52 \%$ of the total number of subjects surveyed, with low S-anxiety $33.10 \%$ and high $13.38 \%$. Consequently, the overwhelming majority of people surveyed show good social adaptation and show resistance to environmental stressors.

When comparing the percentage distribution of the results by period, we find a decrease in the mean rate and an increase in the low anxiety rate (Figure $5)$. 


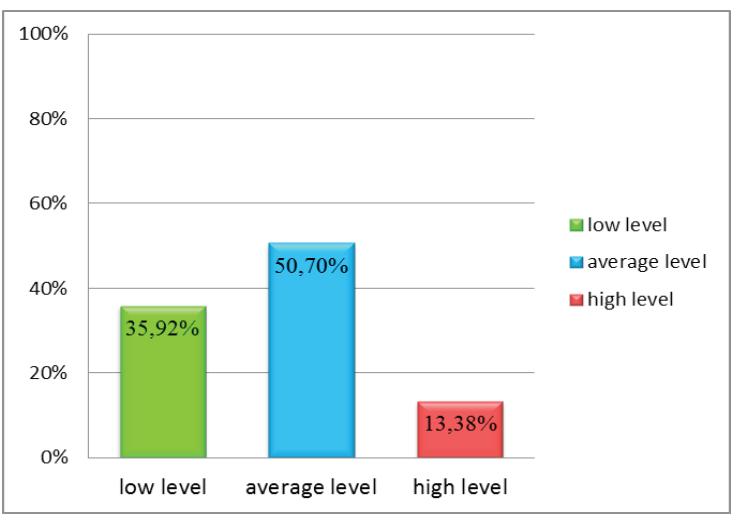

Figure 5. Percentage distribution of the degree of S-anxiety in 2nd study.

Given that high levels of S-anxiety in the second study remain unchanged $(13.38 \%)$, we can conclude that the students who were at an average level of situational anxiety in the first test at the end of the study showed low levels of anxiety. A total of 19 people showed a high level of anxiety in the two tests (over 45 points), 9 of which were women ( $25 \%$ of the women surveyed) and 10 were men $(9.43 \%$ of the men surveyed); in the second 6 are women $(16,66 \%)$ and 13 - men $(12,26 \%)$. This also coincides with the above-mentioned gender data.

\section{Conclusion}

There is a clear tendency to decrease stagnation anxiety over the two periods of the study: at the beginning of the snow sports training it is significantly higher and at the end it is lower. The collected data proves our hypothesis that, despite the probationary nature of the course, the positive emotional side of the course contributes to reducing the anxi- ety of the significant part of the students. The snow sports course does not have a negative impact on them, but we still recommend minimizing the factors that contribute to anxiety.

\section{References}

Domuschieva-Rogleva, G., K. Petkova, (2002) Nivo na samokontrolirashti umenia i trevojnost pri 14-16 godishni handbalisti, Lichnost, motivacia, sport. Sportat i lichnostta. Kniga 1, ProSPort. Sofia // Домусчиева-Роглева, Г., К. Петкова. (2002) Ниво на самоконтролиращи умения и тревожност при 14-16 годишни хандбалисти.- В: Личност, мотивация, спорт. Спортът и личността. Книга 1, ПроСпорт, София.

Khavezova, K., T. Yancheva. (1996) Strakhŭt pri nachalnoto obuchenie po ski. Lichnost, motivatsiya, sport. Tom 2. NSA PRES, Sofiya. // Хавезова, К., Т. Янчева. Страхът при началното обучение по ски. Личност, мотивация, спорт. Том 2. НСА ПРЕС, С., 1996.

Nijkamp M., Kenens C., Dijker A., Ruiter R., Hiddema F., Nuijts R. (2004) Determinants of surgery related anxiety in cataract patients. The British Journal of ophthalmology

Shtetinski, D., I. Paspalanov (1989). Metodichesko posobie za rabota s bulgarskata forma na vuprosnika za otsenka na trevozhnostta na CH. Spilburgur. Sofia. // Щетински, Д., И. Паспаланов. (1989). Методическо пособие за работа с българската форма на въпросника за оценка на тревожността на Ч. Спилбъргър. София.

Spilberger, CH. (1983) Kontseptualni i metodologicheski problemi issledovatelni trevogi.- V: Stress i trevoga v sporte. Moskva // Спилбергер, Ч. (1983) Концептуальные и методологические проблемы исследования тревоги.- В: Стресс и тревога в спорте. Москва

Weinstock L.S. (1999) Gender differences in the presentation and management of social anxiety disorder. J Clin Psychiatry 